\title{
Perbandingan Kemampuan Pemecahan Masalah Matematis Siswa antara Problem Centered Learning dan Problem Based Learning
}

\author{
Erik Rinaldi ${ }^{1}$, Ekasatya Aldila Afriansyah ${ }^{2}$
}

1,2) Institut Pendidikan Indonesia, Indonesia

Correspondence: $\bowtie$ ekafrian@institutpendidikan.ac.id

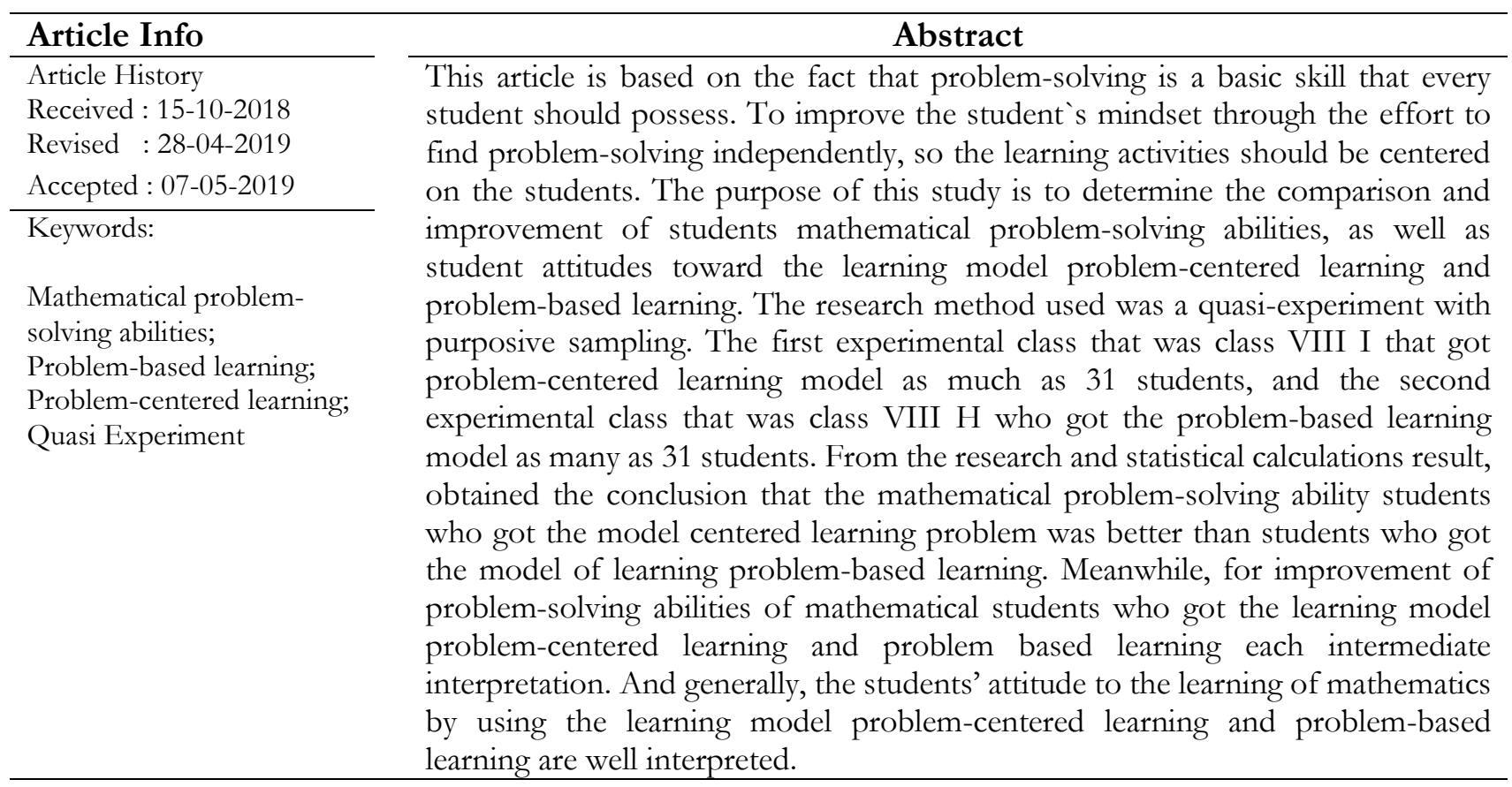

\section{PENDAHULUAN}

Saat ini, di era globalisasi menuntut adanya sumber daya manusia yang berkualitas. Kualitas sumber daya manusia ini salah satunya dapat diperoleh dari proses pembelajaran yaitu melalui pendidikan. Pendidikan merupakan kegiatan yang universal dalam kehidupan manusia, yang memiliki peranan penting dalam mencetak manusia menjadi sumber daya manusia yang handal dan terampil di bidangnya. Dalam pelaksanaan pendidikan, matematika menjadi mata pelajaran wajib yang dipelajari di sekolah.

Adapun tujuan pembelajaran matematika untuk jenjang pendidikan dasar dan menengah berdasarkan Permendiknas No. 22 tahun 2006 pada KTSP 2006 yang disempurnakan pada kurikulum 2013 [1] antara lain agar siswa memiliki kemampuan: 1) Memahami konsep matematika, 2) Menggunakan penalaran pada pola dan sifat, 3) Memecahkan masalah yang meliputi kemampuan memahami masalah, merancang model matematika, 4) Mengomunikasikan gagasan dengan simbol, tabel, diagram, atau media lain, 5) Memiliki sikap menghargai kegunaan matematika dalam kehidupan. Berdasarkan tujuan pembelajaran matematika tersebut, kemampuan pemecahan masalah matematis sangat diperlukan siswa.

Uraian di atas menunjukan bahwa pemecahan masalah merupakan bagian yang cukup penting dalam pembelajaran khususnya matematika. Seperti yang diungkapkan oleh Wahyudin bahwa "Pemecahan masalah adalah bagian integral dari belajar matematika, yaitu bagian yang tidak dapat dipisahkan dalam pembelajaran matematika”. Senada dengan pernyataan Afriansyah [2] yaitu kemampuan pemecahan masalah matematis merupakan kemampuan matematika yang perlu dimiliki oleh siswa. 
Namun pada kenyataannya, memecahkan masalah merupakan salah satu kemampuan yang sukar untuk dipelajari oleh siswa. Selain itu, pencapaian nilai Programme for International Student Assessment (PISA) pada tahun 2015, pada kompetensi matematika Indonesia meraih poin 386 sedangkan rata-rata keseluruhannya 490 poin. Hal tersebut menempatkan Indonesia pada urutan ke 63 dari 70 negara yang mengikuti tes PISA. Capaian tersebut menunjukan bahwa kompetensi matematika Indonesia masih rendah ataupun di bawah rata-rata.

Kemungkinan hal tersebut disebabkan oleh kurang aktifnya siswa dalam belajar dan kesulitan dalam memahami soal pemecahan masalah dan proses penyelesaiannya. Dalam mengerjakan soal-soal, sebagian besar siswa hanya menggunakan langkah-langkah sederhana dan langsung menuliskan jawaban dari pertanyaan soal, tidak menuliskan secara runtut apa yang diketahui, apa yang ditanyakan dan kemudian diselesaikan. Hal tersebut merupakan bukti kurangnya kemampuan menjalankan proses pemecahan masalah matematika yang meliputi memahami masalah, merencanakan penyelesaian masalah, menyelesaikan masalah dan menemukan hasil penyelesaian.

Selain itu, fakta di lapangan menunjukan bahwa guru telah mendominasi setiap kegiatan belajar mengajar di sekolah, sehingga kurangnya kesempatan bagi siswa untuk mengonstruksikan pengetahuan matematika. Guru menjadi pusat dalam pembelajaran yang berarti bahwa pembelajaran masih menggunakan cara konvensional.

Untuk mengatasi permasalahan tersebut, seharusnya guru harus mendorong siswa untuk lebih mandiri menemukan konsep matematika, mengadakan penyelidikan melalui percobaan, menganalisa, serta mendiskusikan dengan anggota kelompoknya supaya pembelajaran menjadi lebih bermakna bagi siswa. Untuk mencapai itu semua, salah satu cara yang dapat ditempuh seorang guru adalah dengan menerapkan model pembelajaran Problem Centered Learning dan Problem Based Learning yang sesuai untuk mengatasi masalah yang terjadi.

Model pembelajaran Problem Centered Learning dan Problem Based Learning merupakan model pembelajaran berbasis masalah. Kedua model tersebut diyakini dapat meningkatkan kemampuan pemecahan masalah matematis siswa.

Model Problem Centered Learning menjadi pembelajaran yang potensial karena model pembelajaran ini ditujukan untuk memperbaiki keadaan pembelajaran yang memungkinkan siswa untuk belajar yang produktif. Siswa perlu dikondisikan dalam suatu keadaan yang memungkinkan baginya untuk melakukan partisipasi secara bebas melalui diskusi-diskusi kelas [3] [4].

Sementara itu, pada penelitian Yusri [5], terdapat kesimpulan bahwa kemampuan pemahaman konsep dan pemecahan masalah matematis siswa yang diajar dengan pendekatan Problem Centered Learning lebih tinggi dari pada siswa yang diajar dengan pembelajaran konvensional. Senada dengan penelitian Dewanti [6], pembelajaran matematika menggunakan perpaduan pendekatan Problem Centered Learning dan pelatihan metakognitif secara signifikan lebih efektif dalam meningkatkan kemampuan pemecahan masalah siswa dibandingkan dengan pendekatan ekspositori. Hal ini berarti model pembelajaran Problem Centered Learning dapat meningkatkan kemampuan pemecahan masalah matematis siswa.

Menurut Arends Problem Based Learning adalah model pembelajaran dimana siswa dihadapkan pada masalah yang autentik (nyata) sehingga diharapkan dapat menyusun pengetahuan sendiri, menumbuh kembangkan inkuiri dan keterampilan tingkat tinggi, memandirikan siswa, dan meningkatkan kepercayaan dirinya [7]. Problem Based Learning berorientasi pada siswa dan mendorong pembelajaran aktif [8]. 
Penelitian sebelumnya disimpulkan bahwa pembelajaran matematika dengan menerapkan Problem Based Learning dapat meningkatkan kemampuan pemecahan masalah matematika siswa [2][9][10]. Sehingga ini merupakan alasan kuat peneliti memutuskan untuk menerapkan model pembelajaran ini.

Berikut adalah beberapa penelitian relevan yang telah menggunakan model pembelajaran Problem Based Learning dan telah terbukti dapat meningkatkan beberapa variabel kemampuan matematis, yaitu: kemampuan berpikir kreatif [11]; kemampuan representasi matematis [12]; kemampuan komunikasi matematis dan kemampuan pemahaman matematis [13].

Adapun rumusan masalah dalam penelitian ini adalah: a) Apakah kemampuan pemecahan masalah matematis siswa yang mendapatkan model pembelajaran Problem Centered Learning lebih baik dibandingkan siswa yang mendapatkan model pembelajaran Problem Based Learning? b) Bagaimana peningkatan kemampuan pemecahan masalah matematis siswa yang mendapatkan model pembelajaran Problem Centered Learning? dan c) Bagaimana peningkatan kemampuan pemecahan masalah matematis siswa yang mendapatkan model pembelajaran Problem Based Learning?

Pemecahan masalah artinya proses melibatkan suatu tugas yang metode pemecahannya belum diketahui lebih dahulu. Untuk memperoleh solusi dari suatu permasalahan, siswa harus mampu mengaitkan pengetahuan yang telah diperolehnya dengan informasi yang baru diperolehnya sehingga dapat membangun pemahaman-pemahaman matematis baru.

Adapun indikator kemampuan pemecahan masalah yang peneliti ambil dalam penelitian ini adalah berdasarkan [14]: 1) Mengidentifikasi kecukupan data untuk pemecahan masalah; 2) Merumuskan masalah matematis atau menyusun model matematis. Membuat model matematika dari suatu situasi atau masalah sehari-hari dan menyelesaikannya; 3) Memilih dan menerapkan strategi untuk menyelesaikan masalah matematika dan atau di luar metematika; 4) Menjelaskan atau menginterpretasikan hasil sesuai permasalahan asal, serta memeriksa kebenaran hasil atau jawaban; dan 5) Menerapkan matematika secara bermakna.

Problem Centered Learning awalnya dikembangkan pada tahun 1986 di sekolah dasar dan pada saat itu pendekatan ini disebut dengan Problem Centered Mathematics atau Problem Centered Classroom, kemudian pada awal tahun 1990, Wheatley mengembangkan pendekatan ini di sekolah menengah dan disebut Problem Centered Learning. Model Problem Centered Learning memungkinkan siswa menstimulasikan pikirannya untuk membuat konsep yang ada menjadi logis menurut mereka berdasarkan masalah yang mereka hadapi dan mengembangkan konsep-konsep tersebut sesuai dengan aturan matematika yang diketahui.

Wheatley [3] menyatakan bahwa, langkah-langkah pembelajaran Problem Centered Learning melibatkan tiga komponen, yaitu sebagai berikut:

1. Mengerjakan tugas: Pertama-tama guru menyiapkan kelas, kemudian menugaskan siswa untuk mengerjakan tugas. Guru harus memilih tugas-tugas yang menantang, tetapi para siswa tidak ditunjukkan prosedur-prosedur khusus untuk memecahakan soal-soal yang menantang.

2. Kegiatan kelompok: Guru mengkondisikan siswa untuk melanjutkan kegiatan kelompok. Langkah kedua ini guru membagi siswa ke dalam kelompok-kelompok kecil berdasarkan kemampuan siswa, di sini siswa diharuskan melakukan kolaborasi dalam aktivitas kelompok untuk menemukan pemecahan dari masalah dari hasil pemikiran meraka sendiri.

3. Berbagi (sharing): Pada langkah terakhir ini, semua siswa disatukan menjadi diskusi kelas. Seluruh anggota dari setiap kelompok bersama-sama berbagi strategi jalan keluar atau solusi yang berbeda. Di sini peran guru hanya berperan sebagai fasilitator dan setiap uasaha dibuat untuk tidak bersifat menilai tetapi hanya bersifat mendorong. 
Sementara itu, Arends mengungkapkan bahwa Problem Based Learning merupakan suatu model pembelajaran dimana siswa dihadapkan pada masalah autentik (nyata) sehingga diharapkan dapat menyusun pengetahuan sendiri, menumbuh kembangkan inkuiri dan keterampilan tingkat tinggi, memandirikan siswa dan meningkatkan kepercayaan dirinya [7].

Pembelajaran dengan menerapkan Problem Based Learning yang digunakan dalam penelitian ini, adalah langkah pembelajaran menurut Arends [15], yang terdiri dari lima langkah utama sebagai berikut: 1) Orientasi siswa pada masalah; 2) Mengorganisasi siswa untuk belajar; 3) Membimbing penyelidikan individual maupun kelompok; 4) Mengembangkan dan menyajikan hasil karya; 5) Analisis dan evaluasi proses pemecahan masalah.

\section{METODE PENELITIAN}

Metode penelitian yang peneliti gunakan dalam penelitian ini adalah metode kuasi eksperimen dengan desain The Nonequivalent Pretest Posttest Control Group Design [7]. Sedangkan untuk pengambilan sampel dilakukan dengan pertimbangan tertentu (purposive sampling) yakni sampel tidak diambil secara random, tetapi peneliti menerima sampel yang sudah ditentukan oleh sekolah. Sampel yang diambil sebanyak dua kelas, yaitu kelas VIII I sebanyak 31 siswa sebagai kelas eksperimen I dengan menggunakan model pembelajaran Problem Centered Learning dan kelas VIII H sebanyak 31 siswa sebagai kelas eksperimen II dengan menggunakan model pembelajaran Problem Based Learning.

Adapun kedua kelas tersebut sebelumnya terlebih dahulu diberikan tes awal (pretest), dengan tujuan untuk mengetahui kemampuan awal dari masing-masing kelas. Kemudian dilaksanakan pembelajaran beberapa pertemuan dengan model pembelajaran yang digunakan. Setelah itu kedua kelas tersebut diberikan tes akhir (posttest) beserta angket untuk mengetahui sikap siswa terhadap pembelajaran selama penelitian.

\section{HASIL DAN PEMBAHASAN}

Dari hasil penelitian, diperoleh hasil tes awal (pretest) dan tes akhir (posttest) dari kelas Problem Centered Learning dan kelas Problem Based Learning. Berikut diuraikan hasil analisis data tersebut.

Tabel 1. Data Kelas Problem Centered Learning

\begin{tabular}{cccc}
\hline Kelas & \multicolumn{3}{c}{ Problem Centered Learning } \\
\hline Tes & Pretest & Posttest & Gain Ternormalisasi \\
Jumlah Siswa & 31 & 31 & 31 \\
Rata-rata & 9,52 & 29,95 & 0,51 \\
Deviasi Standar & 2,74 & 5,14 & 0,12 \\
\hline
\end{tabular}

Tabel 2. Data Kelas Problem Based Learning

\begin{tabular}{cccc}
\hline Kelas & \multicolumn{3}{c}{ Problem Based Learning } \\
\hline Tes & Pretest & Posttest & Gain Ternormalisasi \\
Jumlah Siswa & 31 & 31 & 31 \\
Rata-rata & 11,16 & 26,10 & 0,39 \\
Deviasi Standar & 4,70 & 7,17 & 0,15 \\
\hline
\end{tabular}


Dari tabel 1 dan 2, terlihat bahwa deviasi standar tes awal maupun tes akhir kelas Problem Centered Learning lebih rendah dari pada kelas Problem Based Learning, hal tersebut menunjukan bahwa kemampuan pemecahan masalah matematis kelas Problem Centered Learning lebih menyebar. Sedangkan berdasarkan peningkatan dari kedua kelas Problem Centered Learning dan Problem Based Learning yang di analisis dengan uji Gain Ternormalisasi diperoleh masing-masing rata-ratanya 0,51 dan 0,39, maka peningkatan kedua kelas tersebut masing-masing berinterpretasi sedang.

Tabel 3. Hasil Uji Normalitas Data Tes Awal

\begin{tabular}{|c|c|c|c|}
\hline \multirow{2}{*}{ Kelas } & \multicolumn{2}{|c|}{$\mathbf{L}$} & \multirow{2}{*}{ Kriteria } \\
\hline & $L_{\text {maks }}$ & $L_{\text {tabel }}$ & \\
\hline Problem Centered Learning & 0,1621 & 0,161 & Tidak Berdistribusi Normal \\
\hline Problem Based Learning & 0,1364 & 0,161 & Berdistribusi Normal \\
\hline
\end{tabular}

Dari tabel 3, terlihat bahwa salah satu kelas yaitu kelas Problem Centered Learning tidak berdistribusi normal, maka untuk pengujian selanjutnya menggunakan statistik non parametrik yaitu Uji Mann Whitney.

Sebelum melakukan perhitungan, peneliti merumuskan terlebih dahulu hipotesis nol dan hipotesis alternatifnya, yaitu:

Ho: Tidak terdapat perbedaan yang signifikan antara kemampuan awal siswa kelas Problem Centered Learning dan kemampuan awal siswa kelas Problem Based Learning.

Ha: Terdapat perbedaan yang signifikan antara kemampuan awal siswa kelas Problem Centered Learning dan kemampuan awal siswa kelas Problem Based Learning.

Setelah melakukan perhitungan, diperoleh nilai $z_{\text {hitung }}=1,23<z_{\text {tabel }}=1,64$ dengan demikian Ho diterima, maka dapat disimpulkan bahwa tidak terdapat perbedaan yang signifikan antara kemampuan awal siswa kelas Problem Centered Learning dan kemampuan awal siswa kelas Problem Based Learning.

Tabel 4. Hasil Uji Normalitas Data Tes Akhir

\begin{tabular}{|c|c|c|c|}
\hline \multirow{2}{*}{ Kelas } & \multicolumn{2}{|c|}{$\mathbf{L}$} & \multirow{2}{*}{ Kriteria } \\
\hline & $L_{\text {maks }}$ & $L_{\text {tabel }}$ & \\
\hline Problem Centered Learning & 0,1185 & 0,161 & Berdistribusi Normal \\
\hline Problem Based Learning & 0,1374 & 0,161 & Berdistribusi Normal \\
\hline
\end{tabular}

Dari tabel 4, terlihat bahwa kedua kelas berdistribusi normal, maka untuk pengujian selanjutnya menggunakan Uji Homogenitas Dua Varians. Setelah melakaukan perhitungan diperoleh $F_{\text {hitung }}=$ $1,95>F=1,84$, maka kedua varians tidak homogen. Karena kedua varians tidak homogen, maka untuk menguji kesamaan dua rata-rata kemampuan akhir siswa adalah dengan uji $t^{\prime}$.

Sebelum melakukan perhitungan, peneliti merumuskan terlebih dahulu hipotesis nol dan hipotesis alternatifnya, yaitu:

Ho: Kemampuan pemecahan masalah matematis siswa yang mendapatkan model pembelajaran Problem Centered Learning tidak lebih baik dibandingkan siswa yang mendapatkan model pembelajaran Problem Based Learning. 
Ha: Kemampuan pemecahan masalah matematis siswa yang mendapatkan model pembelajaran Problem Centered Learning lebih baik dibandingkan siswa yang mendapatkan model pembelajaran Problem Based Learning.

Setelah melakukan perhitungan, diperoleh nilai $t^{\prime}=2,43>\frac{w_{1} t_{1}+w_{2} t_{2}}{w_{1}+w_{2}}=1,6973$, sehingga Ho ditolak. Dengan demikian dapat disimpulkan bahwa kemampuan pemecahan masalah matematis siswa yang mendapatkan model pembelajaran Problem Centered Learning lebih baik dibandingkan siswa yang mendapatkan model pembelajaran Problem Based Learning.

Berdasarkan data hasil penelitian yang telah diolah sebelumnya, dapat disimpulkan bahwa kemampuan pemecahan masalah matematis siswa yang mendapatkan model pembelajaran Problem Centered Learning lebih baik dibandingkan siswa yang mendapatkan model pembelajaran Problem Based Learning, dan perbandingannya pun terlihat secara signifikan. Artinya, siswa di kelas Problem Centered Learning lebih meningkat kemampuan pemecahan masalah matematisnya dibandingkan siswa di kelas Problem Based Learning, tetapi dalam hal ini tidak terlepas bahwa kemampuan pemecahan masalah matematis kelas Problem Based Learning pun meningkat.

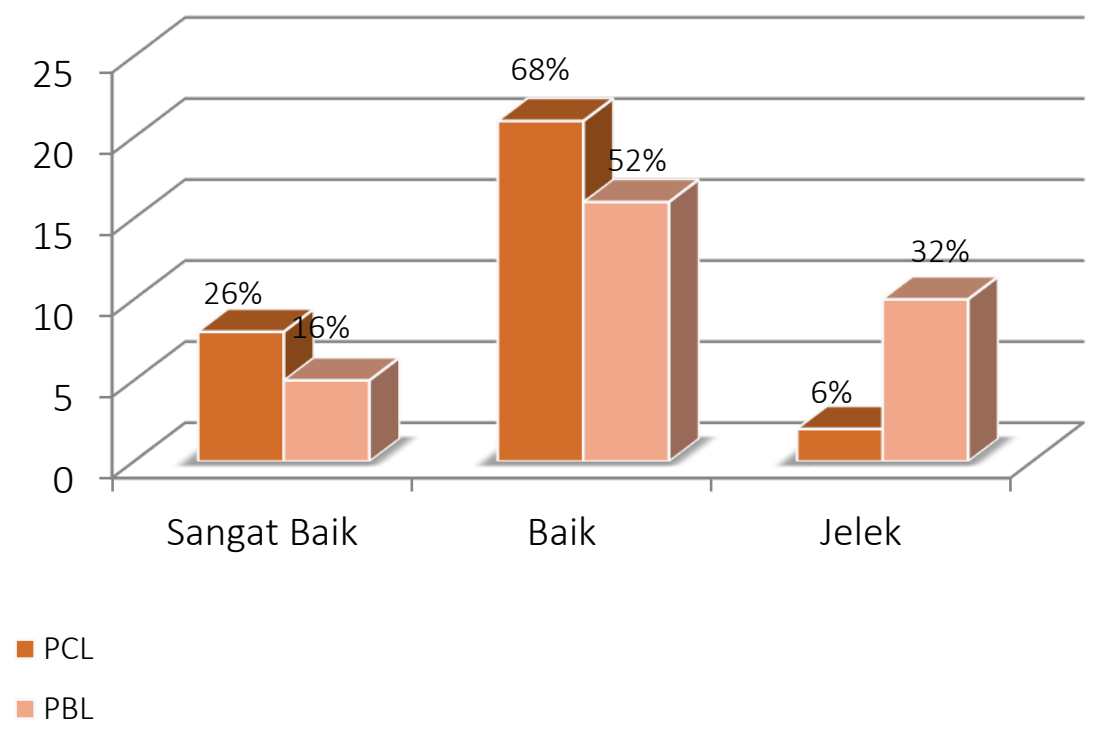

Gambar 1. Persentase Sikap Siswa

Tabel 5. Sikap Siswa secara Keseluruhan

\begin{tabular}{ccccc}
\hline Kelas & Aspek & Jumlah & Total & Keterangan \\
\hline \multirow{2}{*}{ PCL } & Model & 751 & 1905 & Baik \\
& Soal-soal Pemecahan & 1154 & & \\
\multirow{2}{*}{ PBL } & Model & 723 & 1778 & Baik \\
& Soal-soal Pemecahan & 1055 & & \\
\hline
\end{tabular}

Dari gambar 1 terlihat bahwa persentase sikap siswa yang paling banyak untuk masing-masing model adalah pada interpretasi baik, meskipun sebagian ada yang sikapnya pada interpretasi sangat baik dan jelek. 
Secara keseluruhan selama empat kali pertemuan untuk kelas Problem Centered Learning dan kelas Problem Based Learning, kedua kelas tersebut bisa mengikuti proses pembelajaran dengan baik. Hal tersebut dapat dilihat dari hasil angket pada tabel 5 bahwa kedua kelas tersebut menunjukan sikap yang baik terhadap pembelajaran matematika dan juga terhadap soal-soal pemecahan masalah matematis yang diberikan.

Pada saat kegiatan pembelajaran berlangsung, ada beberapa kendala yang peneliti temukan di kelas Problem Centered Learning. Kendala tersebut diantaranya pada awal pertemuan ada beberapa siswa dari kelompok yang kemampuannya rendah tidak mau duduk berkelompok, serta kelompok dengan kemampuan siswanya rendah lambat dalam menyelesaikan lembar kerja siswa.

Selain adanya kendala tersebut peneliti juga menemukan kelebihan-kelebihan ketika pembelajaran di kelas Problem Centered Learning berlangsung. Kelebihan tersebut diantaranya meskipun pembagian kelompoknya homogen yang dilihat dari kemampuan matematikanya, tetapi rasa ingin tahu dan antusias siswa dalam pembelajaran melebihi kelas Problem Based Learning dimana cenderung yang mengerjakan itu siswa tertentu sedangkan yang lainnya kurang terlibat.

Sementara itu, kendala yang peneliti temukan di kelas Problem Based Learning diantaranya beberapa siswa laki-laki yang keluar kelas saat pergantian jam pelajaran, sehingga waktu yang digunakan saat jam pelajaran kurang optimal. Terdapat beberapa siswa yang cenderung tidak serius dalam mengikuti pembelajaran. Hal ini terlihat ketika siswa tersebut yang dominannya laki-laki selalu ribut, ngobrol dengan teman kelompok lain, serta dalam kelompok tidak semuanya bekerja cenderung mengandalkan siswa yang kemampuannya tinggi sehingga pada akhirnya siswa tersebut tidak mengerti terhadap apa yang ada pada lembar kerja siswa.

Selain adanya kendala tersebut, peneliti juga menemukan kelebihan-kelebihan ketika pembelajaran di kelas Problem Based Learning berlangsung. Kelebihan tersebut diantaranya pada kelas Problem Based Learning pembagian kelompoknya heterogen, hal itu membuat kesetaraan sehingga dalam mengerjakan lembar kerja siswa ataupun saat mempresentasikan hasil penemuannya merata tidak ada kelompok yang dominan.

Peneliti melihat ada beberapa kemungkinan faktor yang mempengaruhi hasil penelitian, diantaranya: 1) Masih ada siswa ketika kegiatan pembelajaran berlangsung sibuk dengan kegiatannya sendiri, hanya sebagian siswa tertentu saja yang berperan dalam mengerjakan lembar kerja siswa yang diberikan, sehingga waktu yang digunakan tidak maksimal; 2) Guru dan siswa belum terbiasa menggunakan model pembelajaran Problem Centered Learning dan Problem Based Learning, sehingga aktivitas dan kondisi siswa dalam kegiatan pembelajaran kurang maksimal; dan 3) Kurangnya rasa ingin tahu sebagian siswa dalam belajar matematika.

Hasil yang diperoleh dari penelitian ini senada dengan penelitian Dewanti [6] dan Yusri [5], yang menyatakan bahwa kemampuan pemecahan masalah matematis siswa meningkat ketika diberi pembelajaran dengan menggunakan model pembelajaran Problem Centered Learning.

Dari berbagai penelitian yang sudah peneliti pelajari, telah dilakukan berbagai macam penelitian yang berkaitan dengan satu ataupun dua variabel penelitian yang diteliti dalam penelitian ini. Akan tetapi, belum ada penelitian yang melibatkan keterlibatan antar dua variabel bebas dan satu variabel terikat yang peneliti lakukan, sehingga hal ini merupakan kebaruan dari penelitian ini.

Dokumentasi pada saat kegiatan pembelajaran berlangsung bisa dilihat pada gambar 2 dan 3 . 
Numerical: Jurnal Matematika dan Pendidikan Matematika, Vol. 3 No. 1 Juni 2019, 9-18

Erik Rinaldi, Ekasatya Aldila Afriansyah

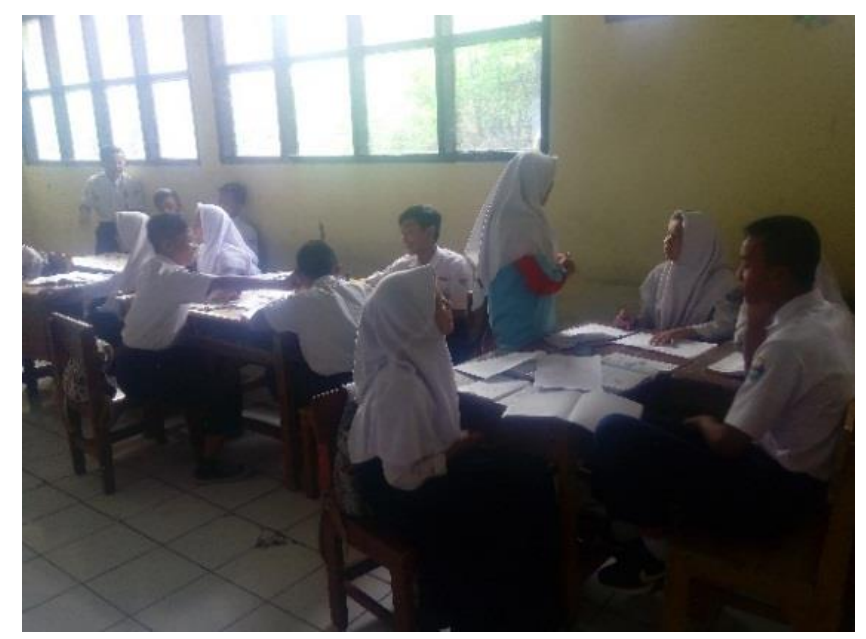

Gambar 2. Kegiatan Pembelajaran di Kelas Problem Centered Learning

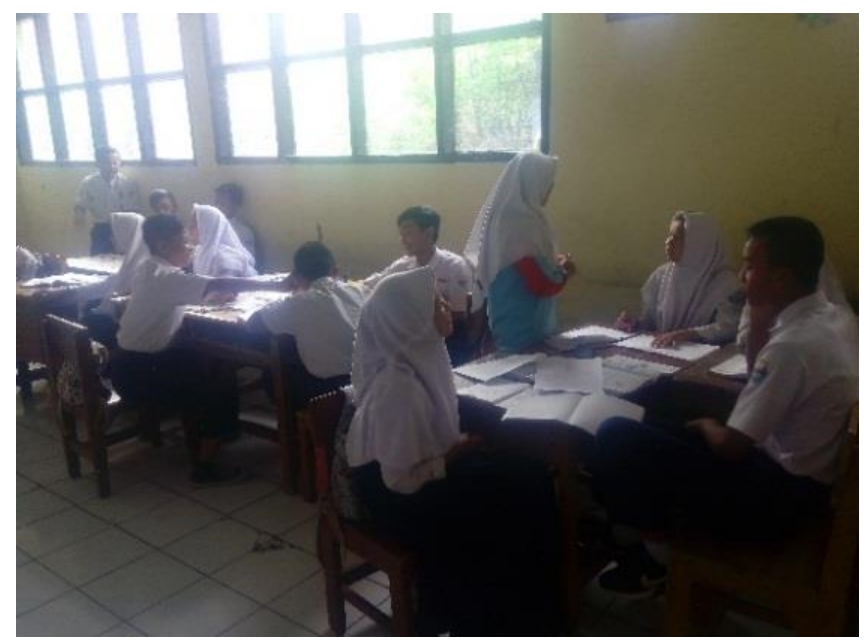

Gambar 3. Kegiatan Pembelajaran di Kelas Problem Based Learning

\section{SIMPULAN DAN SARAN}

Berdasarkan analisis data, hipotesis penelitian, dan pembahasan hasil penelitian yang telah dikemukakan pada pembahasan sebelumnya, diperoleh simpulan bahwa kemampuan pemecahan masalah matematis siswa yang mendapatkan model pembelajaran Problem Centered Learning lebih baik dibandingkan siswa yang mendapatkan model pembelajaran Problem Based Learning. Sementara itu, untuk peningkatan kemampuan pemecahan masalah matematis siswa yang mendapatkan model pembelajaran Problem Centered Learning dan Problem Based Learning masing-masing berinterpretasi sedang. Serta secara umum sikap siswa terhadap pembelajaran matematika dengan menggunakan model pembelajaran Problem Centered Learning dan Problem Based Learning masing-masing berinterpretasi baik.

Berdasarkan penelitian yang telah dilakukan, peneliti memberikan saran dimana secara umum kedua model pembelajaran tersebut dapat memberikan pengaruh sikap positif terhadap pembelajaran matematika, sehingga peneliti menyarankan guru untuk menggunakan model pembelajaran Problem Centered Learning dan Problem Based Learning sebagai salah satu alternatif dalam memilih model pembelajaran di kelas. Selanjutnya pada model pembelajaran Problem Centered Learning pembagian kelompoknya secara homogen, oleh karena itu guru dituntut untuk bisa menjelaskan kepada siswa supaya 
tidak terjadi kecemburuan sosial antar kelompok. Serta penelitian ini hanya berlaku untuk siswa kelas VIII SMP Negeri 4 Tarogong Kidul dengan pokok bahasan bangun ruang sisi datar kubus dan balok. Oleh karena itu, perlu dilakukan penelitian lebih lanjut dengan sekolah, populasi, dan jenjang yang lebih luas serta pokok bahasan yang berbeda.

\section{DAFTAR PUSTAKA}

[1] H. Hendriana and U. Sumarmo, Penilaian Pembelajaran Matematika. Bandung: PT. Refika Aditama, 2014.

[2] E. A. Afriansyah, "Investigasi Kemampuan Problem Solving Dan Problem Posing Matematis Mahasiswa Via Pendekatan Realistic," Mosharafa J. Pendidik. Mat., vol. 5, no. 3, pp. 269-280, Aug. 2018.

[3] R. P. Gunawan, "Model Pembelajaran Problem Centered Learning," 2013.

[4] E. F. Ningsih, "Proses berpikir mahasiswa dalam pemecahan masalah aplikasi integral ditinjau dari kecemasan belajar matematika (Math Anxiety) ”, Jurnal Iqra': Kajian Ilmu Pendidikan., vol. 1, no. 2. 2016.

[5] R. Yusri, "Pengaruh Pendekatan Problem Centered Learning Terhadap Kemampuan Pemahaman Konsep Dan Pemecahan Masalah Matematis Siswa Kelas X SMA Negeri Kabupaten Solok," J. LEMMA, vol. 3, no. 1, Jun. 2017.

[6] S. S. Dewanti, "Perpaduan PCL Dan Pelatihan Metakognitif Dalam Meningkatkan Kemampuan Memecahkan Masalah Matematika," J. Penelit. dan Eval. Pendidikandan Ecaluasi Pendidik., vol. 12, no. 1, pp. 21-39, 2009.

[7] K. E. Lestari and M. R. Yudhanegara, Penelitian Pendidikan Matematika. Karawang: Refika Aditama, 2017.

[8] L. F. Masitoh and H. Fitriyani, "Improving students' mathematics self-efficacy through problem based learning," Malikussaleh J. Math. Learn., vol. 1, no. 1, p. 26, May 2018.

[9] N. Cahyaningrum, "Meningkatkan Kemampuan Pemecahan Masalah Matematika Melalui Penerapan Problem Based Learning Pada Siswa Kelas IX F SMP Negeri Sedayu," Universitas Negeri Yogyakarta, 2010.

[10] M. S. Anwar, "Efektifitas Pembelajaran PBL (Problem Based Learning) Terhadap Kemampuan Berpikir Kritis Dan Kreatif Siswa Materi Tiga Dimensi,” Dec. 2015.

[11] W. Khoiri, R. Rochmad, and A. N. Cahyono, "Problem Based Learning Berbantuan Multimedia dalam Pembelajaran Matematika Untuk Meningkatkan Kemampuan Berpikir Kreatif," Unnes J. Math. Educ., vol. 2, no. 1, Mar. 2013.

[12] M. Farhan and H. Retnawati, "Keefektifan PBL Dan IBL Ditinjau dari Prestasi Belajar, Kemampuan Representasi Matematis, Dan Motivasi Belajar," J. Ris. Pendidik. Mat., vol. 1, no. 2, p. 227, Nov. 2014. 
[13] U. F. Alan and E. A. Afriansyah, "Kemampuan Pemahaman Matematis Siswa Melalui Model Pembelajaran Auditory Intellectualy Repetition dan Problem Based Learning," J. Pendidik. Mat., vol. 11, no. 1, Jan. 2017.

[14] U. Sumarmo, "Kumpulan makalah berpikir dan disposisi matematik serta pembelajarannya," UPI, Bandung, 2013.

[15] D. D. Sari, "Penerapan Model Problem Based Leaning untuk Meningkatkan Kemampuan Berpikir Kritis Peserta Didik Pada Pembeljaran IPA Kelas VIII SMP Negeri 5 Sleman,” Universitas Negeri Yogyakarta, 2012. 